\title{
PENGARUH MODEL BLENDED LEARNING TERHADAP MOTIVASI DAN PRESTASI BELAJAR SISWA SMK
}

\author{
Izuddin Syarif \\ SMKN 1 Paringin, Balangan \\ izuddinsyarif@yahoo.co.id
}

\begin{abstract}
Abstrak: Pengaruh Model Blended Learning terhadap Motivasi Dan Prestasi Belajar Siswa SMK. Penelitian ini bertujuan untuk mengetahui perbedaan motivasi dan prestasi belajar siswa dalam mata pelajaran KKPI antara siswa yang menggunakan model face-to-face learning dan siswa yang menggunakan model blended learning, peningkatan motivasi dan prestasi belajar siswa dalam mata pelajaran KKPI akibat penerapan model blended learning, dan interaksi pengaruh penerapan model pembelajaran dan motivasi terhadap prestasi belajar KKPI siswa SMKN 1 Paringin. Penelitian kuasi eksperimen ini menggunakan dua kelompok, yaitu kelompok eksperimen yang menggunakan model blended learning dan kelompok kontrol yang menggunakan model face-to-face learning. Populasi penelitian adalah siswa kelas XI SMKN 1 Paringin. Sampel penelitian berjumlah 57 siswa terbagi atas 30 siswa kelompok kontrol dan 27 siswa kelompok eksperimen. Pengumpulan data menggunakan kuesioner dan tes soal pilihan ganda. Hasil penelitian menunjukkan ada perbedaan yang signifikan antara motivasi dan prestasi belajar siswa yang menggunakan model blended learning dan siswa yang menggunakan model face-to-face learning, ada peningkatan motivasi dan prestasi belajar siswa yang signifikan akibat penerapan model blended learning, dan tidak terdapat interaksi pengaruh penerapan model pembelajaran dan motivasi terhadap prestasi belajar siswa.
\end{abstract}

Kata kunci: blended learning, face-to-face learning, motivasi, prestasi belajar

\section{THE INFLUENCE OF BLENDED LEARNING MODEL ON MOTIVATION AND ACHIEVEMENT OF VOCATIONAL SCHOOL STUDENT}

\begin{abstract}
The Influence of Blended Learning Model on Motivation and Achievement of Vocational School Student. The objective of the study is to reveal the differences of the learning motivation and achievement of the students using face-to-face learning model compared to those using blended learning model, the improvement of students' learning motivation and achievement due to the use of blended learning model, and the interaction of the effect of learning model and motivation on students' learning achievement in KKPI lesson. This quasi-experimental study used two groups: the experimental group who were taught using blended learning and control group who were taught using face-to-face learning. The population was 11th grade students of SMKN 1 Paringin. A sample of 57 students was divided into 2 groups, with 30 students as the control group and 27 students as the experimental group. The techniques for collecting the data were a test method by giving a written test and non-testing method by distributing a questionnaire. The results of study show that there is significant difference between the learning motivation and achievement of the students using face-to-face learning compared to those using blended learning model, there is a significant increase in learning motivation and achievement due to the use of blended learning model, and there is no interaction of the effect of learning model and motivation on students' learning achievement in KKPI lesson.
\end{abstract}

Keywords: blended learning, face-to-face learning, motivation, learning achievement 


\section{PENDAHULUAN}

Pemerintah

mendorong

konsep

pendidikan berbasis kompetensi dan mendorong pertumbuhan sekolah pendidikan kejuruan (SMK) lewat upaya yang masif dengan membalik rasio SMU dan SMK menjadi $33: 67$ pada tahun 2015. Berbagai langkah strategis dilakukan pemerintah mulai pembangunan fasilitas pendidikan kejuruan seperti gedung sekolah, alat dan bahan praktik sampai peningkatan kualitas guru lewat program diklat dan beasiswa.

Menjadi guru yang profesional adalah keniscayaan yang wajib diwujudkan. Begitu banyak guru yang profesional namun tidak memiliki kemampuan pedagogis yang baik. Kemampuan pedagogis diantaranya kemampuan untuk menyelenggarakan pembelajaran yang mendidik, memanfaatkan teknologi informasi dan komunikasi untuk kepentingan pembelajaran dan memfasilitasi pengembangan potensi siswa untuk mengaktualisasikan berbagai potensi yang dimiliki. Oleh karena itu kebutuhan akan kemampuan guru dalam mengkombinasi berbagai sumber belajar, penggunaan metode yang tepat serta penguasaan materi mutlak diperlukan.

Menurut American Heritage Dictionary, belajar adalah proses untuk mendapatkan pengetahuan, pemahaman atau penguasaan melalui pengalaman atau studi (Hergenhahn and Olson, 2008 : 2). Jika belajar adalah proses mendapatkan pengetahuan maka siswa semestinya didorong untuk aktif mengkonstruksi pengetahuan yang akan didapatkannya dan mencoba menemukan berbagai jawaban dari permasalah yang ditemuinya. Sementara guru berperan sebagai fasilitator dan motivator dalam pembelajaran. lewat peran tersebut maka guru mestinya aktif mengembangkan konsep dan metode pembelajaran yang interaktif dan bermakna bagi siswa. Namun sebagian besar guru masih menggunakan model pembelajaran konvensional seperti pembelajaran tatap muka (face to face learning). Tuntutan dan peradaban telah mengalami pergeseran dari dunia analog menuju dimensi digital lewat kemajuan teknologi informasi yang begiru pesat. Pada saat yang bersamaan guru ditantang untuk memadukan model pembelajaran tradisional dan kemajuan teknologi informasi untuk mengimbangi gaya belajar siswa yang beragam.

Secara umum penggunaan teknologi ICT telah marak berkembang di berbagai sekolah utamanya SMK. Penerapan e-learning merupakan salah satu inovasi teknologi pembelajaran yang mengintegrasikan teknologi informasi dan komunikasi dengan konten pelajaran. Menurut Naidu (2006: 1) e-learning merupakan aktifitas pendidikan secara individu maupun kelompok yang dikerjakan online atau offline lewat jaringan ataupun personal computer serta perangkat elektronik lainnya. Model pembelajaran ini bersifat fleksibel yang memungkinkan peserta e-learning dapat mengakses kapan saja dan darimana saja.

Namun pembelajaran bukan semata bertumpu pada teknologi sebab pembelajaran pada hakikatnya lebih pada proses interaksi antara guru, siswa dan sumber belajar. Meskipun e-learning bisa digunakan secara mandiri oleh siswa, namun eksistensi guru 
menjadi sangat berarti sebagai orang dewasa yang berfungsi memberi dukungan dan mendampingi siswa dalam proses pembelajaran (Plummer, 2012: 1). Dengan kata lain bahwa proses tatap muka menjadi hal yang penting dan tidak boleh ditinggalkan dalam pembelajaran. Oleh karena itu model pembelajaran yang menggabungkan (blending) metode face to face learning dengan e-learning secara integratif dan sistematis akan membuat proses pembelajaran menjadi lebih bermakna.

Penelitian ini bertujuan untuk mengetahui perbedaan motivasi dan prestasi belajar siswa antara pembelajaran dengan model tatap muka (face to face learning) dibanding pembelajaran model blended learning dan peningkatan motivasi dan prestasi belajar karena pengaruh penerapan model pembelajaran. Selain itu penelitian juga bertujuan untuk mengetahui pengaruh interaksi model pembelajaran dan motivasi terhadap peningkatan prestasi belajar siswa SMKN 1 Paringin pada mata pelajaran KKPI.

\section{Motivasi Belajar}

Kata motivasi berasal dari bahasa Latin yaitu movere, yang berarti bergerak (move). Motivasi juga bisa diartikan sebagai usaha yang dapat menyebabkan seseorang atau kelompok orang tertentu tergerak melakukan sesuatu karena ingin mencapai tujuan yang dikehendakinya atau mendapat kepuasan dengan perbuatannya. Menurut Jex (2002: 210) motivasi seperti gravitasi yang tidak bisa dilihat secara visual atau dirasakan namun hanya bisa dilihat efek yang dihasilkan olehnya. Pada kehidupan sehari-hari motivasi memiliki peran yang sangat strategis termasuk pada proses pembelajaran.

Pada proses pembelajaran, motivasi dapat dikatakan sebagai keseluruhan daya penggerak di dalam diri siswa yang menimbulkan kegiatan belajar, yang menjamin kelangsungan dari kegiatan belajar dan memberikan arah pada kegiatan belajar, sehingga tujuan yang dikehendaki oleh subjek belajar itu dapat tercapai (Sardiman, 2000: 75). Jika siswa memiliki motivasi belajar yang tinggi, maka seluruh proses pembelajaran akan diikuti dengan baik mulai dari rasa ingin tahu, intensitas dalam memperhatikan penjelasan pelajaran, membaca materi sampai pada mencari strategi yang paling tepat guna meraih prestasi akademik yang tinggi bagi dirinya. Selain itu Slavin (2009: 106) berpendapat bahwa siswa yang termotivasi akan dengan mudah diarahkan, diberi penugasan, cenderung memiliki rasa ingin tahu yang besar, aktif dalam mencari informasi tentang materi yang dijelaskan oleh guru serta menggunakan proses kognitif yang lebih tinggi untuk mempelajari dan menyerap pelajaran yang diberikan. Menurut Halonen and Santrock (1999: 349) setidaknya terdapat 3 faktor kognitif dalam berprestasi yaitu: (1) attribution, (2) intrinsic and extrinsic motivation, dan (3) goal setting and planning

Menurut Woolfolk (2004: 351) motivasi secara umum terbagi dua yaitu: (1) intrinsic motivation, dan (2) extrinsic motivation. Motivasi intrinsik (intrinsic motivation), yaitu motivasi internal untuk melakukan sesuatu demi sesuatu itu sendiri (tujuan itu sendiri). Sementara motivasi ekstrinsik (extrinsic 
motivation), yaitu melakukan sesuatu untuk mendapatkan sesuatu yang lain (cara untuk mencapai tujuan). Motivasi ekstrinsik sering dipengaruhi oleh insentif eksternal seperti imbalan dan hukuman. Kedua faktor tersebut harus mendapat perhatian yang besar dari seorang guru, terlebih dalam upaya peningkatan prestasi belajar siswa. Motivasi berprestasi menurut Wade \& Tavris (2008: 459) menekankan pada tujuan dan alasan yang dimiliki seseorang untuk mengejar tujuan tersebut. Tujuan berfungsi efektif meningkatkan motivasi dengan memenuhi 3 hal berikut ini: (1) tujuan mesti bersifat spesifik, (2) tujuan harus menantang, namun dapat dicapai, dan (3) tujuan dibatasi pada mendapatkan apa yang diinginkan, bukannya menghindari apa yang tidak diinginkan. Motivasi berprestasi mendorong seseorang untuk belajar dengan giat guna mencapai tujuan yang telah ditetapkannya. Setidaknya terdapat 6 indikator motivasi belajar siswa (Herminarto Sofyan dan Hamzah B. Uno, 2004: 24):

1. hasrat dan keinginan berhasil,

2. dorongan dan kebutuhan dalam belajar,

3. harapan dan cita-cita masa depan,

4. penghargaan dalam belajar,

5. kegiatan yang menarik dalam belajar, dan

6. lingkungan belajar yang kondusif.

\section{Prestasi Belajar}

Penyelenggaraan pendidikan di sekolah dilakukan melalui proses belajar mengajar. Pada pelaksanaannya tidak selalu berjalan dengan baik, karena sering terdapat hambatan. Hambatan itu akan dapat diatasi apabila proses belajar mengajar dilakukan dengan disiplin.
Proses pembelajaran yang berlangsung di sekolah mengacu pada kurikulum yang telah dirumuskan oleh semua pihak yang kompeten. Kurikulum memuat sejumlah standar kompetensi yang wajib dipenuhi dan menjadi indikator prestasi belajar siswa. Menurut Slavin (2009: 271) prestasi belajar siswa diukur sejauhmana konsep atau kompetensi yang menjadi tujuan pembelajaran (instructional objective) atau tujuan perilaku (behavioral objective) mampu dikuasai siswa pada akhir jangka waktu pengajaran.

Prestasi belajar adalah suatu usaha atau kegiatan anak untuk menguasai bahan-bahan pelajaran yang diberikan guru di sekolah. Prestasi belajar adalah istilah yang telah dicapai individu sebagai usaha yang dialami secara langsung. Menurut Didin Mukodim, Ritandiyono dan Harumi Ratna Sita (2004: 112), prestasi belajar adalah hasil penilaian pendidik terhadap proses dan hasil belajar siswa yang menggambarkan penguasaan siswa atas materi pelajaran atau perilaku yang relatif menetap sebagai akibat adanya proses belajar yang dialami siswa dalam jangka waktu tertentu.

Prestasi belajar siswa memperlihatkan bahwa dirinya telah mengalami proses belajar dan telah mengalami perubahan-perubahan baik perubahan dalam memiliki pengetahuan, keterampilan, ataupun sikap. Prestasi belajar dapat menunjukkan tingkat keberhasilan seseorang setelah melakukan proses belajar dalam melakukan perubahan dan perkembangannya. Hal ini disebabkan prestasi belajar merupakan hasil penilaian atas kemampuan, kecakapan dan keterampilan- 
keterampilan tertentu yang dipelajari selama masa belajar. Oleh karena itu Johnson (2009: 30) menegaskan bahwa seorang guru harus menyiapkan serangkaian tes yang bertujuan untuk menyimpulkan prestasi belajar siswa meliputi: (1) ketuntasan pada materi tertentu dalam kurikulum, (2) kemampuan kognitif, dan (3) potensi siswa.

Sementara itu menurut Daryanto (2009: 51) terdapat beberapa faktor yang mempengaruhi proses belajar siswa, yaitu:

1. Faktor Intern, meliputi: kondisi jasmani, kondisi psikologis dan faktor kelelahan siswa

2. Faktor Ekstern, meliputi: faktor keluarga, faktor sekolah, faktor masyarakat

\section{Blended Learning}

Penggunaan apalikasi teknologi informasi (e-learning) sebagai media pembelajaran sudah semakin sering ditemui dalam pendidikan. Konsep e-learning tentunya memberi nuansa baru bagi proses pendidikan yang selama ini hanya bertumpu pada eksistensi guru. Menurut Clark \& Mayer (2008: 10) bahwa e-learning adalah pembelajaran yang disajikan dengan bantuan komputer. Huruf "e" dalam e-learning bermakna bahwa materi yang diberikan berbentuk digital sehingga dapat disimpan dalam perangkat elektonik. E-learning memberi ilustrasi bahwa dengan adanya teknologi informasi dan komunikasi, khususnya internet, pembelajaran menjadi lebih terbuka (open) dan fleksibel (flexible), terjadi kapan saja, dimana saja dan dengan dan kepada siapa saja di lokasi mana saja (distributed), berbasis komunitas. Menurut Castle and McGuire (2010: 36), e- learning mampu meningkatkan pengalaman belajar sebab siswa dapat belajar dimanapun dan dalam kondisi apapun selama dirinya terhubung dengan internet tanpa harus mengikuti pembelajaran tatap muka (face to face learning).

Blended learning adalah suatu pendekatan yang fleksibel untuk merancang program yang mendukung campuran dari berbagai waktu dan tempat untuk belajar. Menurut Rovai and Jordan (2004: 3) model blended learning pada dasarnya merupakan gabungan keunggulan pembelajaran yang dilakukan secara tatap muka (face to face learning) dan secara virtual (e-learning). Pembelajaran online atau e-learning dalam blended learning menjadi perpanjangan alami dari pembelajaran ruang kelas tradisional yang menggunakan model tatap muka (face to face learning).

Lewat model blended learning, proses pembelajaran akan lebih efektif karena proses belajar mengajar yang biasa dilakukan (conventional) akan dibantu dengan pembelajaran secara $e$-learning yang dalam hal ini berdiri di atas infrastruktur teknologi informasi dan bisa dilakukan kapanpun dan dimanapun. Selain itu menurut Jusoff and Khodabandelou (2009: 82), blended learning bukan hanya mengurangi jarak yang selama ini ada diantara siswa dan guru namun juga meningkatkan interaksi diantara kedua belah pihak.

Berdasarkan proportion of content delivered online, Allen dkk (2007: 5) memberikan kategorisasi yang jelas terhadap blended learning, traditional learning, web facilitated dan online learning. 
Dari tabel 1 dapat diketahui bahwa sebuah pembelajaran dikatakan berbentuk blended atau hybrid ketika porsi e-learning berada pada kisaran 30-79\% digabungkan dengan tatap muka (face to face learning). Di sisi lain, dengan adanya model blended learning maka mendorong pendidik untuk merubah paradigma pendidikan dari techer-centered learning menuju student-centered learning.

Tabel 1. Proportion of Content Delivered Online

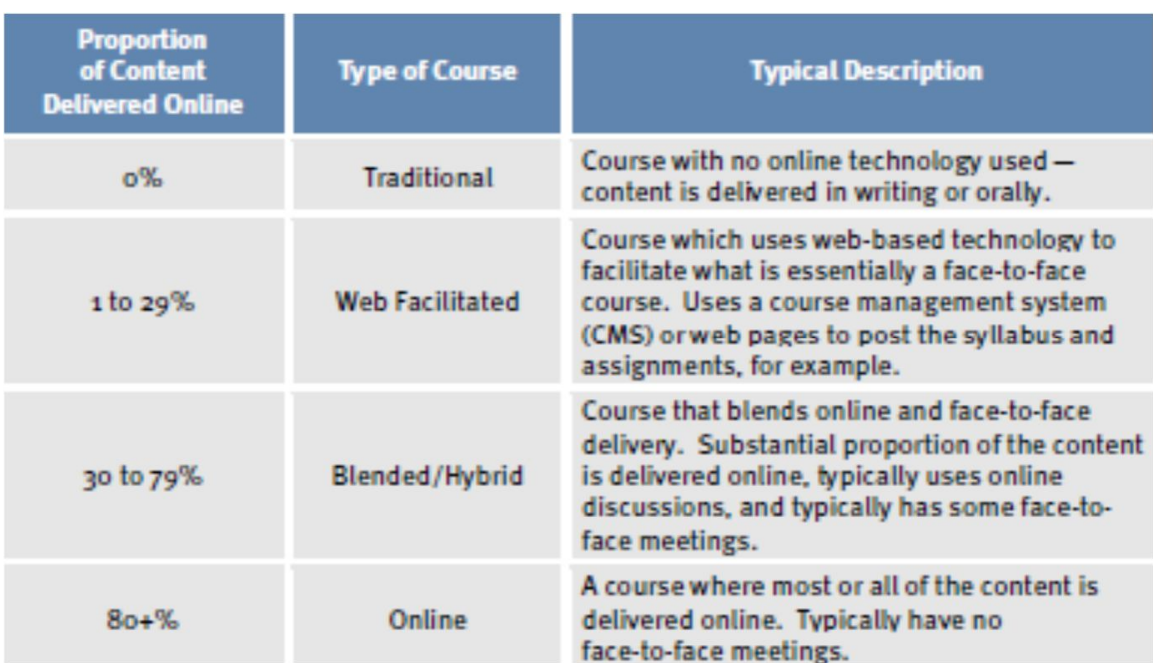

Source: Allen, E, Seaman, J \& Garrett, R. (2007). Blending in: The extent and promise of blended education in United States, Annual Report, Sloan Consortium

Menurut Carman (2005: 2), ada lima kunci untuk melaksanakan pembelajaran dengan menggunakan blended learning, yaitu:

1. Live Event, pembelajaran langsung atau tatap muka secara sinkronous dalam waktu dan tempat yang sama ataupun waktu sama tapi tempat berbeda.

2. Self-Paced Learning, yaitu mengkombinasikan dengan pembelajaran mandiri (self-paced learning) yang memungkinkan peserta belajar kapan saja, dimana saja secara online.

3. Collaboration, mengkombinasikan kolaborasi, baik kolaborasi pengajar, maupun kolaborasi antar peserta belajar.

4. Assessment, perancang harus mampu meramu kombinasi jenis assessmen online dan offline baik yang bersifat tes maupun non-tes.

5. Performance Support Materials, pastikan bahan belajar disiapkan dalam bentuk digital, dapat diakses oleh peserta belajar baik secara offline maupun online.

\section{METODE}

Penelitian ini termasuk jenis penelitian kuantitatif dengan pendekatan quasieksperimental designs. Kelompok yang digunakan pada penelitian berjumlah 2 kelompok, yaitu kelompok eksperimen yang menggunakan pembelajaran model tatap muka (face to face learning) dan kelompok kontrol yang menggunakan pembelajaran model campuran (blended learning). 
Tabel 2. Nonequivalent Group Design

\begin{tabular}{lccc}
\hline \hline Kelompok & $\begin{array}{c}\text { Pre- } \\
\text { Test }\end{array}$ & Treatment & $\begin{array}{c}\text { Post- } \\
\text { Test }\end{array}$ \\
\hline \hline Eksperimen & $\mathrm{O}$ & $\mathrm{X}_{1}$ & $\mathrm{O}$ \\
Kontrol & $\mathrm{O}$ & $\mathrm{X}_{2}$ & $\mathrm{O}$ \\
\hline
\end{tabular}

Keterangan :

$\mathrm{O}$ : Pemberian instrumen angket motivasi dan tes tertulis pada kelompok eksperimen dan kelompok kontrol.

$\mathrm{X}_{1}$ : Pembelajaran dengan menggunakan model blended learning

$\mathrm{X}_{2}$ : Pembelajaran dengan menggunakan model tatap muka (face to face learning).

Tempat penelitian berlokasi di SMK Negeri 1 Paringin, Kabupaten Balangan Propinsi Kalimantan Selatan. Eksperimen ini dilakukan pada semester genap yang didesain selama 6 kali pertemuan (6 minggu) tanggal 9 Pebruari - 15 Maret 2012. Populasi dalam penelitian ini adalah kelas XI semua kompetensi keahlian di SMK Negeri 1 Paringin yang terdiri atas 4 kelas dengan total siswa 118 orang. Komposisi jumlah siswa perkelas sebagai berikut: (1) kelas XI KRA 30 siswa, (2) kelas XI KRB 27 siswa, (3) kelas XI AVI 27 siswa, dan (4) kelas XI Intrik 34 siswa. Seluruh siswa di keempat kelas tersebut pada prinsipnya memiliki kemampuan dasar komputer yang relatif sama.

Penentuan kelas kontrol dan kelas eksperimen dilakukan dengan teknik pengundian dari keempat kelas yang telah terbentuk, sementara 2 kelas yang tersisa diundi lagi untuk menentukan kelas ujicoba instrumen. Instrumen pengumpulan data adalah lembar kuesioner untuk motivasi siswa dan lembar tes soal pilihan ganda untuk prestasi belajar siswa. Kedua instrumen tersebut diberikan sebelum dan sesudah pembelajaran pada masing-masing kelompok sampel yang berlangsung sebanyak 6 kali pertemuan. Data yang diperoleh kemudian dianalisis dan diuji dengan statistik parametrik uji-f, uji-t dan uji univariat.

\section{PEMBAHASAN}

Berikut ini deskripsi data hasil penelitian untuk setiap kelompok:

Tabel 3. Deskripsi Data Penelitian Kelas Kontrol

\begin{tabular}{|c|c|c|c|c|}
\hline & $\begin{array}{c}\text { Motivasi } \\
\text { Awal }\end{array}$ & $\begin{array}{l}\text { Motivasi } \\
\text { Akhir }\end{array}$ & Pretest & Posttest \\
\hline Valid & 30 & 30 & 30 & 30 \\
\hline Mean & 89,6667 & 89,7667 & 62,7633 & 72,8583 \\
\hline Median & 90,5000 & 92,0000 & 62,8600 & 74,2900 \\
\hline Mode & 93,00 & 92,00 & $54,29(a)$ & 74,29 \\
\hline Std. Deviation & 5,86829 & 7,24775 & 10,10847 & 8,03806 \\
\hline Variance & 34,437 & 52,530 & 102,181 & 64,610 \\
\hline Minimum & 71,00 & 72,00 & 48,57 & 60,00 \\
\hline Maximum & 99,00 & 103,00 & 82,86 & 88,57 \\
\hline
\end{tabular}


Tabel 4. Deskripsi Data Penelitian Kelas Eksperimen

\begin{tabular}{|c|c|c|c|c|}
\hline & $\begin{array}{c}\text { Motivasi } \\
\text { Awal }\end{array}$ & $\begin{array}{c}\text { Motivasi } \\
\text { Akhir }\end{array}$ & Pretest & Posttest \\
\hline Valid & 27 & 27 & 27 & 27 \\
\hline Mean & 96,7037 & 99,4074 & 62,0119 & 79,6848 \\
\hline Median & 96,0000 & 99,0000 & 60,0000 & 80,0000 \\
\hline Mode & 97,00 & 103,00 & $54,29(a)$ & 85,72 \\
\hline Std. Deviation & 6,35982 & 7,36551 & 8,70922 & 8,01610 \\
\hline Variance & 40,447 & 54,251 & 75,850 & 64,258 \\
\hline Minimum & 84,00 & 83,00 & 45,72 & 62,86 \\
\hline Maximum & 110,00 & 117,00 & 80,00 & 91,43 \\
\hline
\end{tabular}

Berdasarkan hasil uji normalitas dan homogenitas, maka seluruh kelompok data telah dinyatakan memenuhi syarat.

Tabel 5. Hasil Uji Persyaratan Analisis

\begin{tabular}{ccc}
\hline \multirow{2}{*}{ Data Skor } & \multicolumn{2}{c}{ Nilai P terhadap $\alpha$} \\
\cline { 2 - 3 } & \multicolumn{1}{c}{ Uji Normalitas } & Uji Homogenitas \\
\hline \hline Kelompok Kontrol & $0,758>0,05 \rightarrow$ Normal & $0,166>0,05 \rightarrow$ Homogen \\
\hline Motivasi Awal & $0,472>0,05 \rightarrow$ Normal & \\
Motivasi Akhir & $0,560>0,05 \rightarrow$ Normal & $0,064>0,05 \rightarrow$ Homogen \\
Pretest & $0,696>0,05 \rightarrow$ Normal & \\
Posttest & & $0,385>0,05 \rightarrow$ Homogen \\
\hline Kelompok Eksperimen & $0,594>0,05 \rightarrow$ Normal \\
\hline $\begin{array}{l}\text { Motivasi Awal } \\
\text { Motivasi Akhir }\end{array}$ & $0,990>0,05 \rightarrow$ Normal & \\
Pretest & $0,605>0,05 \rightarrow$ Normal & $0,912>0,05 \rightarrow$ Homogen \\
Posttest & $0,335>0,05 \rightarrow$ Normal & \\
\hline Gain Skor & & $0,201>0,05 \rightarrow$ Homogen \\
\hline Motivasi & $0,124>0,05 \rightarrow$ Normal & $0,715>0,05 \rightarrow$ Homogen \\
\hline Prestasi Belajar & $0,377>0,05 \rightarrow$ Normal
\end{tabular}


Tabel 6. Output Anova Gain Skor Motivasi

\begin{tabular}{lrrrrr}
\hline \hline & Sum of Squares & Df & Mean Square & F & \multicolumn{1}{c}{ Sig. } \\
\hline \hline Between Groups & 96,337 & 1 & 96,337 & 4,211 & 0,045 \\
Within Groups & 1258,330 & 55 & 22,879 & & \\
Total & 1354,667 & 56 & & & \\
\hline
\end{tabular}

Hasil analisis pada tabel 6 membuktikan secara signifikan adanya perbedaan motivasi belajar siswa antara pembelajaran dengan face to face learning dibanding dengan blended learning. Hal tersebut terlihat dari nilai sig. output $(\mathrm{P})$ 0,045 yang berada dibawah 0,05 $(\alpha)$.

Tabel 7. Output Paired Samples t-Test Motivasi Belajar Siswa

Paired Differences

\begin{tabular}{ccccccccc}
\multirow{2}{*}{ Mean } & \multirow{2}{*}{$\begin{array}{c}\text { Std. } \\
\text { Deviation }\end{array}$} & $\begin{array}{c}\text { Std. Error } \\
\text { Mean }\end{array}$ & $\begin{array}{c}\text { 95\% Confidence of the } \\
\text { Difference }\end{array}$ & \multicolumn{2}{c}{ t } & df & $\begin{array}{c}\text { Sig. } \\
\text { (2tailed) }\end{array}$ \\
\cline { 5 - 6 } & & & Lower & Upper & & & \\
\hline$-2,70370$ & 5,08251 & 0,97813 & $-4,71428$ & $-0,69313$ & $-2,764$ & 26 & 0,010 \\
\hline
\end{tabular}

Pada tabel 7, terbukti secara signifikan adanya peningkatan motivasi belajar siswa SMKN 1 Paringin dalam mata pelajaran KKPI akibat penerapan model blended learning. Hal tersebut terlihat dari nilai sig. output (P) 0,010 yang berada dibawah $0,05(\alpha)$.

Tabel 8. Rerata Skor Motivasi Belajar Siswa

\begin{tabular}{cccccc}
\hline \hline \multicolumn{3}{c}{ Model Face to Face Learning (F2F) } & \multicolumn{3}{c}{ Model Blended Learning (BLEND) } \\
Awal (A) & Akhir (B) & B - A & Awal (A) & Akhir (B) & B - A \\
\hline 89.67 & 89.77 & 0,10 & 96.70 & 99.41 & 2,70 \\
Peningkatan motivasi 0,10 point (0,11\%) & Peningkatan motivasi 2,7 point (2,8\%) \\
\multicolumn{2}{c}{ Peningkatan motivasi model BLEND terhadap F2F 2,60 point (26x) } \\
\hline
\end{tabular}

Berdasarkan tabel 8 dan gambar 1 dapat dilihat bahwa rerata skor motivasi belajar siswa kelas kontrol meningkat 0,10 point $(0,11 \%)$. Sementara itu rerata skor motivasi belajar siswa kelas eksperimen yang meningkat 2,70 point $(2,8 \%)$. Jika dibandingkan peningkatan rerata skor motivasi belajar kedua kelompok maka peningkatan motivasi belajar siswa kelas eksperimen lebih besar 2,60 point (26 kali lipat) dibandingkan peningkatan skor motivasi belajar siswa kelas kontrol. 


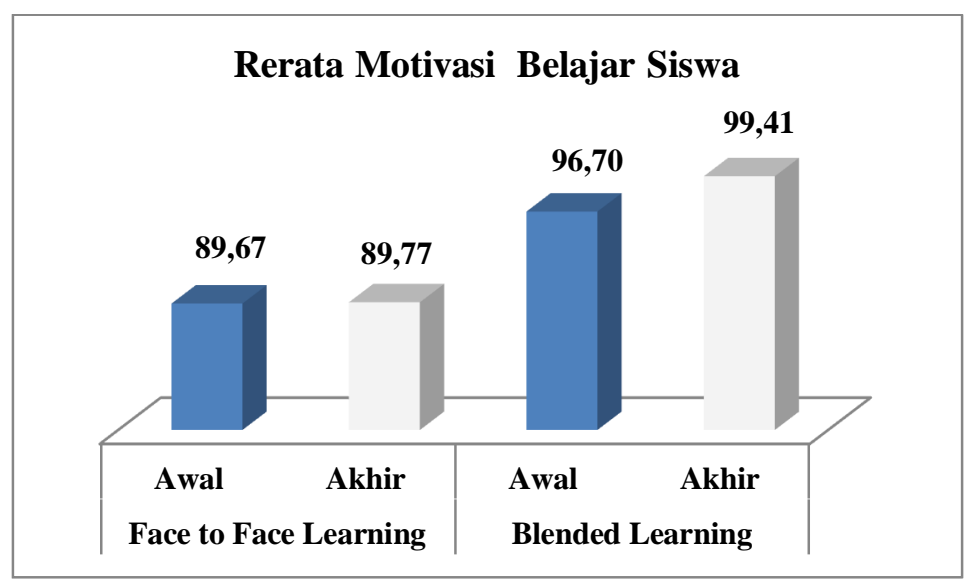

Gambar 1. Diagram Batang Rerata Motivasi Belajar Siswa

Tabel 9. Tabel 9. Output Anova Gain Skor Prestasi Belajar

\begin{tabular}{lrrrrr}
\hline \hline & Sum of Squares & Df & Mean Square & F & \multicolumn{1}{c}{ Sig. } \\
\hline \hline Between Groups & 816.047 & 1 & 816.047 & 8.311 & .006 \\
Within Groups & 5400.212 & 55 & 98.186 & & \\
Total & 6216.259 & 56 & & & \\
\hline
\end{tabular}

Hasil analisis pada tabel 9 membuktikan secara signifikan adanya perbedaan prestasi belajar siswa antara pembelajaran dengan face to face learning dibanding pembelajaran blended learning. Hal tersebut terlihat dari nilai sig. output (P) 0,006 yang berada dibawah 0,05 $(\alpha)$.

Tabel 10. Output Paired Samples t-Test Prestasi Belajar Siswa

\begin{tabular}{|c|c|c|c|c|c|c|c|}
\hline \multirow{3}{*}{ Mean } & \multicolumn{4}{|c|}{ Paired Differences } & \multirow{3}{*}{$\mathrm{t}$} & \multirow{3}{*}{$\mathrm{df}$} & \multirow{3}{*}{$\begin{array}{c}\text { Sig. } \\
\text { (2tailed) }\end{array}$} \\
\hline & \multirow{2}{*}{$\begin{array}{c}\text { Std. } \\
\text { Deviation }\end{array}$} & \multirow{2}{*}{$\begin{array}{l}\text { Std. Error } \\
\text { Mean }\end{array}$} & \multicolumn{2}{|c|}{$\begin{array}{l}\text { 95\% Confidence of the } \\
\text { Difference }\end{array}$} & & & \\
\hline & & & Lower & Upper & & & \\
\hline$-17,67296$ & 10,11815 & 1,94724 & $-21,67557$ & $-13,67036$ & $-9,076$ & 26 & 0,000 \\
\hline
\end{tabular}

Selain itu hasil analisis selanjutnya pada tabel 10, membuktikan secara signifikan adanya peningkatan prestasi belajar siswa SMKN 1 Paringin dalam mata pelajaran KKPI akibat penerapan model blended learning. Hal tersebut terlihat dari nilai sig. output (P) 0,000 yang berada dibawah $0,05(\alpha)$. 
Tabel 11. Rerata Skor Prestasi Belajar Siswa

\begin{tabular}{cccccc}
\hline \hline \multicolumn{2}{c}{ Model Face to Face Learning (F2F) } & \multicolumn{3}{c}{ Model Blended Learning (BLEND) } \\
Pretest (A) & Posttest (B) & B - A & Pretest (A) & Posttest (B) & B - A \\
\hline \hline 62.76 & 72.86 & 10,10 & 62.01 & 79.68 & 17,67 \\
Peningkatan prestasi 10,10 point (16\%) & Peningkatan prestasi 17,67 point $(28,5 \%)$ \\
\multicolumn{2}{r}{ Peningkatan prestasi belajar model BLEND terhadap F2F 7,58 point (75\%) } \\
\hline
\end{tabular}

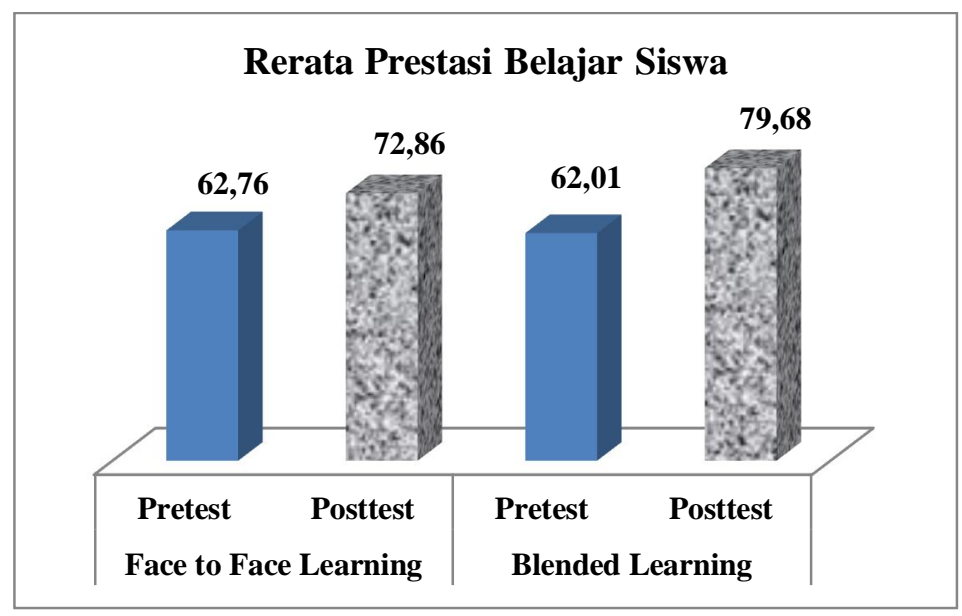

Gambar 2. Diagram Batang Rerata Prestasi Belajar Siswa

Pada tabel 11 dan gambar 2 menunjukkan adanya peningkatan prestasi belajar siswa di masing-masing kelompok. Peningkatan terbesar terjadi pada siswa kelas eksperimen. Rerata skor prestasi belajar siswa kelas kontrol meningkat signifikan 10,10 point (16\%). Sementara itu rerata skor prestasi belajar siswa kelas eksperimen meningkat signifikan 17,67 point $(28,5 \%)$. Jika dibandingkan keduanya maka peningkatan skor prestasi belajar siswa kelas eksperimen lebih besar 7,58 point (75\%) dibanding peningkatan prestasi belajar siswa kelas kontrol.

Pembelajaran dengan model blended learning mampu menggeser prinsip pembelajaran dari teacher center menuju student center secara dinamis. Pembelajaran model blended learning bersifat saling melengkapi kekurang pembelajaran model face to face learning dan e-learning, sebab menurut Munir (2009: 176) kelemahan pembelajaran $e$ elearning diantaranya siswa dan guru terpisah secara fisik sehingga interaksi secara tatap muka menjadi berkurang. Selain itu e-elearning cenderung pada pelatihan daripada pendidikan yang mengarah pada kemampuan kognitif dan psikomotirk dan kurang memperhatikan aspek afektif. Lewat face to face learning guru mampu memfungsikan dirinya sebagai pendidik dan memberikan dorongan motivasi secara langsung dan ekspresif pada siswa. Model blended learning membuat aktifitas siswa dalam kelas menjadi lebih variatif. Siswa tidak hanya bertumpu pada informasi yang disampaikan oleh 
guru, namun berusaha mengupayakan informasi

tersebut dari berbagai sumber.

Tabel 12. Test of Between-Subjects Effects

\begin{tabular}{|c|c|c|c|c|c|c|}
\hline Source & $\begin{array}{l}\text { Type III } \\
\text { Sum of } \\
\text { Squares }\end{array}$ & df & Mean Square & $\mathrm{F}$ & Sig. & $\begin{array}{l}\text { Partial Eta } \\
\text { Squared }\end{array}$ \\
\hline $\begin{array}{l}\text { Corrected } \\
\text { Model }\end{array}$ & 1043.148(a) & 3 & 347.716 & 3.562 & .020 & .168 \\
\hline Intercept & 10878.780 & 1 & 10878.780 & $\begin{array}{r}111.45 \\
6\end{array}$ & .000 & .678 \\
\hline Motivasi & 220.462 & 1 & 220.462 & 2.259 & .139 & .041 \\
\hline Model & 796.309 & 1 & 796.309 & 8.158 & .006 & .133 \\
\hline $\begin{array}{l}\text { motivasi } * \\
\text { model }\end{array}$ & 11.321 & 1 & 11.321 & .116 & .735 & .002 \\
\hline Error & 5173.111 & 53 & 97.606 & & & \\
\hline Total & 16890.491 & 57 & & & & \\
\hline Corrected Total & 6216.259 & 56 & & & & \\
\hline
\end{tabular}

Analisis selanjutnya pada tabel 12 belajar tidak berpengaruh secara signifikan ditemukan tidak ada pengaruh interaksi antara terhadap peningkatan prestasi belajar siswa. model pembelajaran dan motivasi belajar siswa Oleh karena itu peningkatan prestasi belajar terhadap prestasi belajar. Analisis juga siswa benar-benar disebabkan oleh penerapan memperlihatkan pada penelitian ini motivasi model pembelajaran jenis blended learning.

Tabel 13. Deskriptif Motivasi*Model Pembelajaran Terhadap Prestasi Belajar Siswa

\begin{tabular}{llrl}
\hline \multicolumn{1}{c}{ Motivasi } & \multicolumn{1}{c}{ Model } & \multicolumn{2}{c}{ Mean } \\
\hline \hline Rendah (R) & Face to face (F) & 8.571 & \\
& Blended (B) & 15.167 & \\
& Selisih RB - RF & 6.596 & $76.95 \%$ \\
Tinggi (T) & Face to face (F) & 11.619 & \\
& Blended (B) & 20.000 & \\
& Selisih TB - TF & 8.381 & $72.14 \%$ \\
\hline Selisih TF - RF (X) & & 3.047 & $35.55 \%$ \\
\hline Selisih TB - RB (Y) & & 4.833 & $31.87 \%$ \\
\hline
\end{tabular}

Berdasarkan tabel 13 dapat dilihat bahwa jumlah rerata prestasi belajar kedua kelompok siswa yang bermotivasi tinggi dan rendah sudah berbeda. Jika ditelaah lebih lanjut trend rerata 
prestasi belajar siswa baik kelompok motivasi tinggi maupun yang motivasi rendah mengalami peningkatan. Terdapat selisih rerata prestasi belajar siswa bermotivasi rendah (RB-RF) dari 8,571 menjadi 15,167 (76,95\%). Sementara itu terdapat selisih rerata prestasi belajar siswa bermotivasi tinggi (TB-TF) dari 11,619 menjadi $20,000(72,14 \%)$. Pada tabel yang sama juga didapatkan selisih rerata prestasi belajar siswa yang bermotivasi tinggi terhadap siswa yang bermotivasi rendah pada pembelajaran face to face (TF-RF) sebesar 3,047 point $(35,55 \%)$ dan selisih rerata prestasi belajar siswa yang bermotivasi tinggi terhadap siswa yang bermotivasi rendah pada pembelajaran blended learning (TB-RB) sebesar 4,833 point (31,87\%).

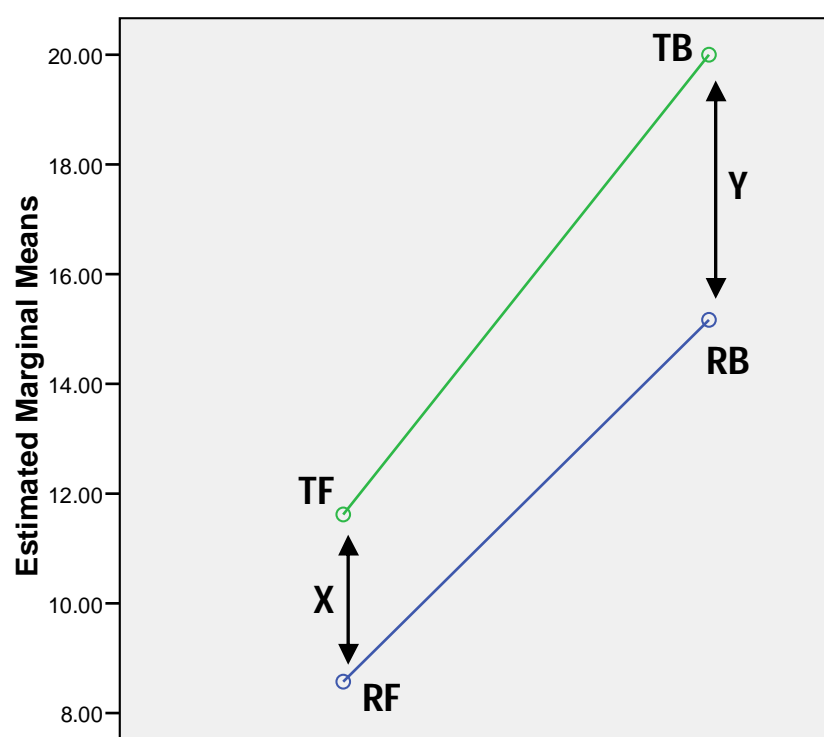

Gambar 3. Grafik Interaksi Motivasi dan Model Pembelajaran terhadap Prestasi Belajar Siswa

Pada gambar 3 terlihat kemiringan garis diagonal TF-TB dan RF-RB yang dibentuk oleh kedua kelompok siswa terlihat relatif sejajar namun tidak berimpit. Selain itu selisih TF-RF
(X) dan TB-RB (Y) pada gambar 3 relatif tidak jauh berbeda.

Menurut Herminarto Sofyan dan Hamzah B. Uno (2004: 30) motif merupakan suatu tenaga potensial untuk terjadinya perilaku atau tindakan. Pada gambar 3 terlihat bagaimana stimulus berupa model pembelajaran telah meningkatkan motivasi kedua kelompok untuk belajar, namun motif kedua kelompok cenderung menghasilkan tenaga potensial yang relatif sama $(\mathrm{TB}-\mathrm{TF}=72,14 \%$ dan $\mathrm{RB}-\mathrm{RF}=$ 76,95\%). Kelompok siswa yang bermotivasi rendah tidak mampu secara maksimal merespon stimulus berupa model pembelajaran guna mencapai prestasi belajar yang sama atau lebih tinggi dibanding kelompok siswa yang bermotivasi tinggi. Hal ini terlihat dari selisih prestasi belajar kedua kelompok pada kedua perlakuan (X dan Y).

Berdasarkan teori atribusi (Woolfolk, 2004: 354) terdapat 3 dimensi yang mempengaruhi karakteristik atribusi: (1) locus, (2) stability, dan (3) controllability. Model pembelajaran yang diterapkan pada kedua kelas merupakan stimulus dari luar (external) yang bersifat stabil (stable) dan respon yang dihasilkan bersifat uncontrollable. Oleh karena itu motivasi belajar yang terbentuk akibat pengaruh penerapan model blended learning tidak berpengaruh signifkan terhadap peningkatan prestasi belajar siswa. Peningkatan prestasi belajar secara signifikan hanya disebabkan oleh treatment yang diberikan pada siswa yaitu penerapan model pembelajaran.

Pada teori kontrol (cybernetics), dijelaskan bagaimana individu melakukan 
kontrol terhadap setiap rangsang yang diterimanya sesuai dengan titik kontrol atur (set point) dalam dirinya (Hill, 2010: 268). Setiap stimulus direspon sesuai dengan titik atur (set point) pada masing-masing individu. Kelompok siswa yang bermotivasi rendah maupun kelompok siswa yang bermotivasi tinggi merespon stimulus berupa model pembelajaran dalam titik atur masing-masing. Jika diperhatikan kembali gambar 3 maka dapat diilustrasikan adanya set point yang yang menimbulkan motivasi berprestasi pada kedua kelompok siswa. Siswa yang bermotivas tinggi sudah terbiasa dengan aktifitas belajar dan motif berprestasi sehingga cenderung terus mempertahankan posisinya. Sementara itu siswa yang bermotivasi rendah juga berperilaku yang sama tanpa ada keinginan (set point) yang lebih tinggi seperti keinginan untuk meningkatkan prestasi belajar melebihi siswa yang lebih baik prestasinya. Menurut Wade \& Travis (2007: 190) motivasi berprestasi akan menghasilkan peningkatan prestasi belajar yang maksimal jika siswa mampu mengkombinasikan motivasi yang terbentuk baik intrinsik maupun ekstrinsik akibat model pembelajaran dengan kemampuan untuk mendemonstrasikan kinerjanya tersebut.

Oleh karena itu penerapan model pembelajaran yang berpengaruh signifikan pada peningkatan motivasi belajar sesungguhnya menjadi modal dasar bagi respon selanjutnya berupa peningkatan prestasi belajar siswa. Namun kita perlu menyadari bahwa motivasi merupakan faktor psikis yang kompleks. Menurut Herminarto Sofyan dan Hamzah B. Uno, motivasi yang terkuat adalah motivasi intrinsik dibandingkan motivasi ekstrinsik. Senada dengan hal itu Woolfolk dalam educational psychology (2004: 352) menyatakan bahwa proses pembelajaran harus mampu menciptakan motivasi intrinsik siswa dengan menghubungkan minat siswa dan mendukung perkembangan kompetensinya. Selain menerapkan model pembelajaran untuk membangkitkan motivasi secara eksternal maka guru mesti mengupayakan agar motivasi instrinsik terus dikembangkan sebab motivasi itulah yang mampu memberi dorongan terbesar bagi pengembangan potensi siswa menjadi sebuah kemampuan.

\section{SIMPULAN}

Berdasarkan hasil penelitian maka disimpulkan sebagai berikut:

1. Terdapat perbedaan motivasi belajar secara signifikan antara kelas yang menggunakan model face to face learning dengan kelas yang menggunakan model blended learning.

2. Terdapat perbedaan prestasi belajar secara signifikan antara kelas yang menggunakan model face to face learning dengan kelas yang menggunakan model blended learning.

3. Motivasi belajar siswa meningkat secara signifikan karena penerapan model pembelajaran blended learning.

4. Prestasi belajar siswa meningkat secara signifikan karena penerapan model pembelajaran blended learning.

5. Tidak terdapat pengaruh interaksi penerapan model pembelajaran dan 
motivasi terhadap prestasi belajar siswa.

Oleh karena itu peningkatan prestasi belajar siswa benar-benar dipengaruhi secara signifikan oleh penerapan model pembelajaran

\section{UCAPAN TERIMA KASIH}

Puji syukur pada Allah SWT yang telah memberi segala kemudahan sehingga penelitian ini berhasil diselesaikan dengan baik. Selain itu perlu kiranya penulis mengucapkan terima kasih yang tak terhingga pada:

1. Pemerintah Propinsi Kalimantan Selatan dan Pemerintah Kabupaten Balangan yang telah memberi kesempatan penulis untuk menuntut pendidikan yang lebih tinggi

2. Jajaran pimpinan, seluruh dosen dan staf Program Pascasarjana Universitas Negeri Yogyakarta yang telah memberi layanan pendidikan luar biasa bagi penulis

3. Pimpinan, para pengajar dan seluruh siswa SMK Negeri 1 Paringin yang telah memfasilitasi penelitian ini.

4. Seluruh pihak yang tidak bisa disebutkan satu persatu

Semoga segala daya upaya yang telah dicurahkan mendapat balasan berupa rahmat dan berbagai kemudahan serta hal terbaik lainnya dari Allah SWT, amin.

\section{DAFTAR PUSTAKA}

Allen, IE, Seamen, J. \& Garret, R. 2007. Blending in: The extent and promise of blended education in the United States, USA: The Sloan Consortium.

Carman, J.M. 2005. Blended learning design: Five key ingredients, diunduh 20 Maret
2011, dari

http://www.agilantlearning.com/pdf/Blen ded\%20Learning\%-20Design.pdf

Castle, SR. \& McGuire, CJ. 2010. An analysis of student self assessment of online, blended, and face to face learning environments: implication for sustainable education delivery. (Versi elektronik). Journal of International Education Studies., vol 3 no 3, 36.

Clark, R.C., Mayer, R.E. 2008. e-Learning and the science of instruction, 2nd Ed, San Francisco: Pfeiffer.

Daryanto. 2009. Panduan proses pembelajaran kreatif dan inovatif, Jakarta: AV Publisher

Didin Mukodim, Ritandiyono dan Harumi Ratna Sita. 2004. Peranan kesepian dan kecenderungan internet addiction disorder terhadap prestasi belajar mahasiswa universitas gunadarma, Proceedings Komputer dan Sistem Intelijen, Jakarta, 1411-6286, diunduh 13 Oktober 2011 dari http://research.mercubuana.ac.id/proceedi ng/Didin_111-120.pdf

Halonen, J.S. \& Santrock, J.W. 1999. Psychology: contexts \& application, Boston: McGraw-Hill College

Hergenhahn, B.R., Olson, M.H. 2008. Theories of learning (Terjemahan Tri Wibowo), Jakarta: Kencana Prenada Media. (Buku asli diterbitkan tahun 2008)

Herminarto Sofyan dan Hamzah B. Uno. 2004. Teori motivasi dan aplikasinya dalam penelitian, Gorontalo: Nurul Jannah.

Hill, W.F. 2010. Theories of learning, (Terjemahan M. Khozim), Bandung: Nusa Media. (Buku asli diterbitkan tahun 1990)

Jex, S.M. 2002. Organizational psychology: a scientist-practitioner approach, New York: John Wiley \& Sons

Johnson, R.L., Penny, J.A. \& Gordon, B. (2009). Assessing performance: designing, scoring, and validating performance tasks, New York: The Guilford Press

Jusoff, K. \& Khodabandelou, R. 2009. Preliminery study on the role of social presence in blended learning environment in higher education. (Versi elektronik). 
Journal of International Education Studies., vol 2 no 4, 82.

Munir. 2009. Pembelajaran jarak jauh: berbasis teknologi informasi dan komunikasi, Bandung: Alfabeta

Naidu, Som. 2006. E-learning: a guidebook of principles, procedures and practices, New Delhi: Aishi Creative Workshop.

Plummer, Lisa. 8 Maret 2012. Credit recovery programs combine the best of online and in class instruction, diunduh pada tanggal 27 Maret 2012 dari http://thejournal.com/Articles/2012/03/08/ Online-credit-recovery.asp $\mathrm{x}$ ? $=1$

Rovai, A.P., Jordan, H.M. 2004. Blended learning and sense of community: a comparative analysis with traditional and fully online graduate courses,
International Review of Research in Open and Distance Learning, Vol. 5, Number 2, 1492-3831, diunduh 25 Agustus 2011, dari

http://www.irrodl.org/index.php/irrodl/arti cle/viewFile/192/795

Sardiman A.M. 1994. Interaksi dan motivasi belajar dan mengajar, Jakarta: RajaGrafindo Persada.

Slavin, R.E. 2009. Psikologi pendidikan : Teori dan praktik, (Terjemahan Marianto Samosir), Jakarta: Indeks. (Buku asli diterbitkan tahun 2006)

Wade, C. \& Tavris, C. 2008. Psychology $9^{\text {th }}$ edition, Boston: Pearson Education

Woolfolk, Anita. 2004. Educational psychology, Boston: Pearson Education, Inc. 